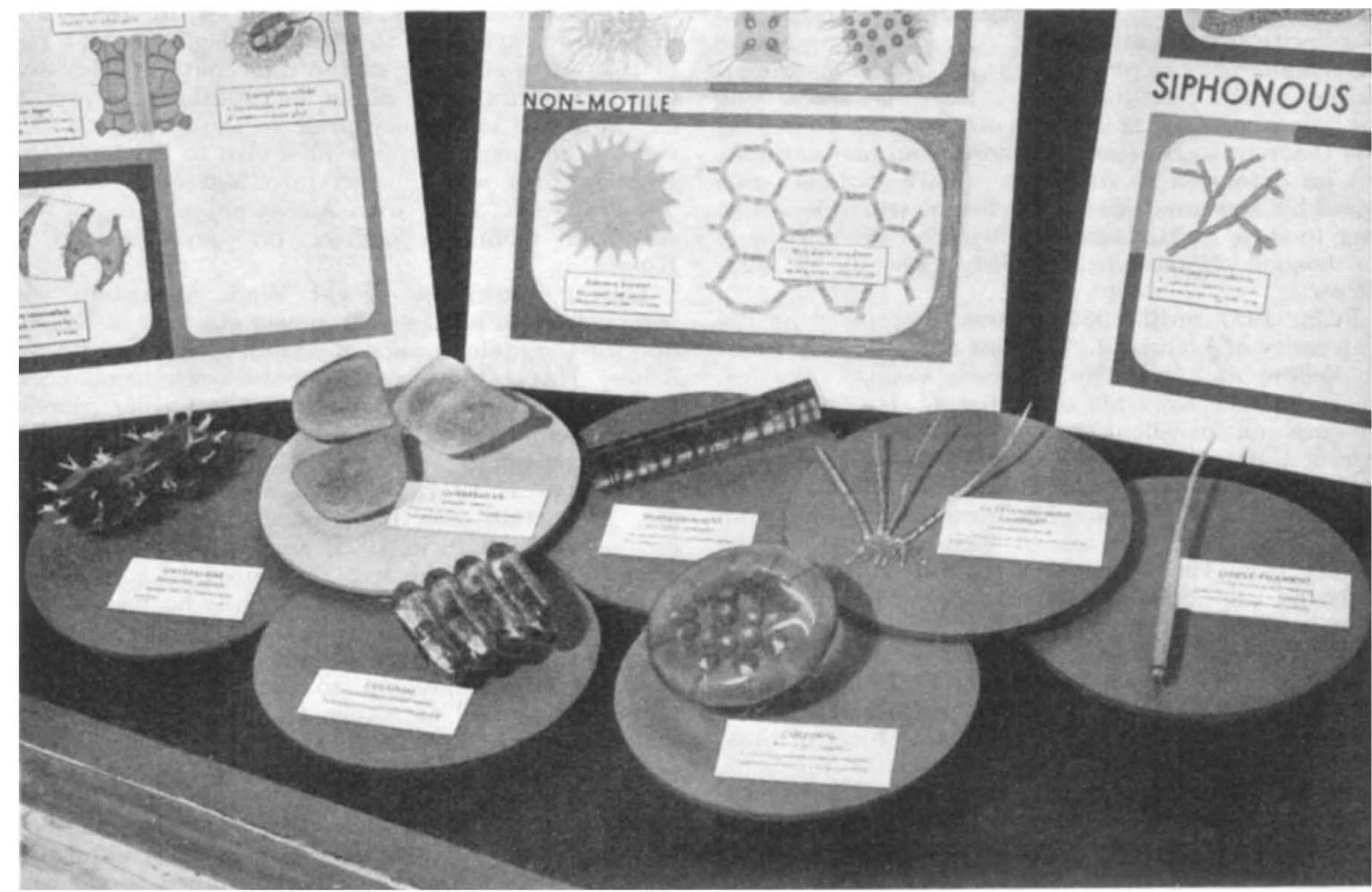

Fig. 3. A series of plastic models to illustrate the increasing complexity of structure in the algae, from unicellular species to those with a complex heterotrichous system of fllaments

feel that if we present even a brief glimpse of the network of reactions controlled by enzymes we shall have achieved something.

The dioramas, which are supported by ample teaching material, form our main ecological exhibits. Each exhibit is designed to emphasize one or more basic ecological principles. Thus, the sand dune/salt marsh exhibit deals with succession in space and time, while in the British mountain case the importance of underlying rock in the determination of the land-forms, soil and flora developed is stressed. The Himalayan diorama illustrates the importance of altitude in determining the vertical zonation of vegetation, and the British mountain exhibit demonstrates the effect of altitude on individual plants. The exhibits produced jointly with the Nature Conservancy are concerned with the establishment and scientific management of nature reserves, especially the need for fundamental ecological research before sound management plans can be formulated. What more appropriate end could there be to a biological gallery ? Unless everyone becomes aware of the need for the right use of natural resources, the efforts of disarma- ment commissions alone will not be sufficient to preserve a world fit to live in.

We should like to commend to our fellow scientists the need for continuing improvement in our relations with the general public. This is no new idea; but it is obvious that many opportunities remain to be taken. There can be no doubt that in problerns like conservation the eleventh hour is already with us, while an informed and sympathetic public opinion must form the soundest basis for expanding research. In the last analysis the public holds the purse strings for most scientific research and development and is entitled to full information, both on recent progress and the broad picture of each major branch. A public which foels that scientists have little patience with their ignorance and no time to make their work comprehensible to the layman, is less likely to support scientific research than one whose interest has been stimulated by sound information made freely available. If our new gallery has made some contribution to explaining not only botany but also the kind of work on which modern botanists are engaged, we shall not feel that we have failed.

\title{
OBITUARIES
}

\section{Dr. U. S. Haslam-Jones}

Dr. Ughtred Shuitleworth Haslam-Jones, who died on August 7, was the son of the Rev. M. A. Haslam-Jones, then Baptist minister of Hackney, London, but later a clergyman of the Church of England. He was born on July 12, 1903, and educated at various schools as his father moved from one church to another. From Ealing County School he obtained a mathomatical scholarship to Queen's College, Oxford, in 1921. At Oxford he was awarded Firsts and the junior and senior mathematical scholarships, and then took a D.Phil. degree under the supervision of G. H. Hardy.

His thesis on the theory of functions of a complex variable contained a more memorable result than such efforts usually do. There is a well-known theorem 
of Hadamard that if the function $f(z)=\Sigma a_{n} z^{n}$ has singularities at points $\alpha_{1}, \alpha_{2}, \ldots$ and $g(z)=\Sigma b_{n} z^{n}$ has singularities at points $\beta_{1}, \beta_{2}, \ldots$, then the singularities of the function $\mathrm{F}(z)=\Sigma a_{n} b_{n} z^{n}$ are among the points $\alpha_{m} \beta_{n}$. It is far from obvious how to extend this theorem to functions of more than one variablo, but an extension to functions of two variables was found by Haslam-Jones. The result, which is not so easy to state as Hadamard's, is in the Proceedings of the London Mathematical Society (Ser. 2, 27, 223; 1928).

From 1927 until 1936 he was a lecturer at the University of Liverpool. The rest of his life was spent as Fellow and tutor of Queen's College, Oxford, where ho succeeded his old tutor, C. H. Thompson. $\mathrm{He}$ was an excellent tutor and was also highly regarded as a lecturer, his usual topie being the theory of functions of a real variable. He served on the Council of the London Mathematical Society from 1937 until 1944, and was a vice-president of tho Society from 1940 until 1942. From 1940 until his death he was an editor of the Quarterly Journal of Mathematics.

His main sciontific interest was in the theory of functions of a real variable, and he published a series of papers on this subject, some of them in collaboration with Dr. J. C. Burkill. The main object of these papers is to show that even very irregular functions, which are not necessarily differentiable in the ordinary sense, still have derivatives in some generalized or approximate sense, except possibly in sets of points of measure zero.

He was a friendly and loyal colleague and will be much missed by all in Oxford.

\section{E. C. Trtohmarsh}

\section{Mr. Simeon M. Alsenstein}

THE death occurred on September 3 at Chelmsford of $\mathrm{Mr}$. Simeon M. Aisenstein, a pioneer of radio communication in Europe, particularly in the development of thermionic valves.
Mr. Aisenstoin was born at Kiev in 1884, and directed his attention to wireless telegraphy as a boy of 16. After studying at the University of Kiev and Charlottenburg Polytechnic, he established a private experimental laboratory prior to the formation of a wireless company. Following a visit to England, this Russian firm was merged into Marconi's Wireloss Telegraph Co., Ltd., with Aisenstein as director and principal technical adviser on developments in Russia.

During the First World War, Aisenstein was responsible for all the high-power stations in Russia, and for the maintenance of communications with the Allies. He conducted experimental work in collaboration with the Army and Navy, including pioneer trials in communication with submerged submarines which attracted the attention of the British Admiralty. In 1917, during the Bolshevik revolution, Mr. Aisenstein was imprisoned, but managed to escape to England in 1921, and joined the Marconi Co. A year later ho was appointed to a company established by Marconi's in Poland: he was instrumental in the development of this company, particularly in the manufacture of radio valves. In 1935 he went to Czechoslovakia to set up another valve factory, but had to return to Chelmsford in 1939 . Here he was at first engaged in the design of radio equipment, and later took over the valve laboratories of the Company. On the formation of the English Electric Valve Co., Ltd., in 1947, he became the first general manager, a position he held until his retirement in 1955, after which he continued to act as a consultant to the Company.

Mr. Aisenstein had boen professor at the Moscow Higher Technical School and a vice-president of the Russian Society of Radio Engineers. In recognition of his service, he was appointed a Councillor of State for the Russian Empire in 1915, and was made an Officer of the Legion of Honour by the French Government in the following year. He was the author of many patents and a number of scientific and technical papers.

\section{NEWS and VIEWS}

Bacteriology at St. Andrews: Prof. W. J. Tulloch

Pror. W. J. Tulloon has just retired after occupying the chair of bacteriology at Queen's College, Dundee (University of St. Andrews), for 41 years. Throughout this long poriod, Tulloch brilliantly fulfilled the doublo role of teacher and research worker besides being dean of the Medical Faculty for many years and supervising the ever-growing diagnostic bacteriological sorvicos for both hospital and local authorities. Ho was an indefatigable and meticulously careful bench worker, and his publications eonsist largely of a series of major studies - on the mechanism of agglutination, the anaerobic infections of war wounds including the serological types of the tetanus bacillus, the laboratory diagnosis of smallpox, the occurrence of tubercle bacilli and brucellæ in milk, diphtheritic infections in a partially im. munized community, and the laboratory diagnosis of gonococcal infections. In most of theso fields of study, he was a pioneer who blazed the trail for others to follow. He gave the Harben Lectures in 1934, and for the Lister Lecture of the Royal College of Physicians, Edinburgh, in 1956, he took as his theme "Medicine as an Aspect of General Biology". Tulloch loved to teach and to the end undertook practically all the formal lectures to the undergraduate classes. He was a dramatic and very effective teacher and even in the vivas at the pro. fessional examinations, he answorod most of his own questions. Undoubtedly he inspired many young men both in and outside his department, and these 'old boys' will long chorish their association with the maestro.

Prof. J. P. Duguid

DR. J. P. Duguin, who succeeds Prof. W. J. Tulloch, is an Edinburgh man, born and bred. Educated at Edinburgh Academy, ho went up to the University at the age of 17 and graduated with honours in both science and medicine. After some hospital experience, ho was appointed lecturer in bactoriology in 1944, became senior lecturer in 1954 and was given the status of reador in 1960 . He gained his M.D. with honours and a gold medal in 1949. Like his predecessor, Duguid is outstanding both as teacher and research worker. In 